Historic, Archive Document

Do not assume content reflects current scientific knowledge, policies, or practices. 

$Y$ circulating this little pamphlet, it is our purpose to serve the public to the best of our ability -offering only nursery products of quality - trees true to name and free of disease.

We have been engaged in the peach industry for about twenty-seven years, now having fifty acres in orchard. We have tested all varieties of fruit and those named herein have proven to be the very best for commercial and home and orchard planting in this section of the country. Seven years ago we began to operate a nursery to serve and supply commercial planters, and our present volume of business convinces us that this service will spread throughout the entire South.

We are offering at this time one hundred thousand trees and shrubs from our nursery - trees backed up by us. Next year we expect to place several hundred thousand plants, so if you do not care to plant this year, we will be glad to serve you later.

In addition to the sale of trees, we are in position to personally supervise the planting of all nursery products through our extension service.

With the advent of the boll-weevil, now is the time to diversify. Insure your future by planting good orchards and through the modern marketing facilities you will become independent.

We will be pleased to hear from you.

TAYLOR BROTHERS NURSERY, InC. 


\section{PEACH TREES}

We have only twenty thousand peach trees to offer this year, and suggest that you mail your order promptly.

\section{One Year Trees}

(1) $\$ 0.25$ each

(30 each

4 to 5 feet_............................... each

5 to 6 feet_.....................

2 year old, 4 to $6 \mathrm{ft} . \ldots .50$ each

Write for wholesale prices on one and two year old trees.

\section{VARIETIES :}

MAYFLOWER-Earliest peach grown; ripens one week before the Sneed; solid red color; beautiful appearance; markets well, not being tender like the sneed. A very prolific bearer; ripens from the 20 th to 30 th of May.

GREENSBORO-Beautifully colored, dark red and crimson. Ripens from the 15 th to 30 th of June.

CARMAN-A new acquisition in the peach line; fine variety; ripens from 1 st to the 10 th of July; good shipper and very prolific.

BELLE OF GEORGIA-Very large, flesh white, firm and of excellent flavor. Very showy and prolific. Ripens July 10th. One of the best market peaches. Freestone.

ELBERTA-Very large and hardy in tree and bud; most prolific of all the yellow freestones; juicy with high flavor. Well tested and sells for highest price. Best commercial and shipping peach on the market today. Not less than two thousand should be set for shipping purposes. We grow more of these than any other.

AUGBERT-A late Elberta; very prolific. Ripens 15 th to 25th of August; good seller. Comes in when all other peaches are gone. Large openstone. Good local market peach.

MARTEN SEPTEMBER-Fruit medium size. color, yellow ground with carmine marbling. Thin down. Flesh white-red at the stone, firm granular. Very sweet and rich, with little juice. Its good quality, and its freedom from rot, and capacity to keep and ship well makes it a most valuable market peach. Ripens 1 st of September to 1 st of October.

STENSON'S OCTOBER-Cling: Very fine quality, ripens and keeps well; first-class late variety.

\section{JUNE BUDS :}

Golden Sweet Cling, large yellow peach; ripens last of July.

Old Homestead, a yellow Indian freestone; ripens first of August.

Elberta Cling, large yellow peach ripening with Elberta; very fine in quality.

Honey Dew, medium to large, red all over, very high color; a seedling originated by us.

Alton, medium to large white freestone; ripens first of June; rich, melting and delicious. 
Champion, one of the best flavored peaches on the market today; it deserves its name.

Heath Cling, a white peach ripening in October.

J. H. Hale, the best profit producer and the brightest and most beautiful peach; the best shipping peach on the market; never fails; large.

Lendon Cling, the best yellow cling for canning we have; won the prize at State and County fair.

Red Bird Cling, a fine new peach which will fill a long felt want for a hardy early peach for the South. Flesh juicy, rich, firm and most delicious. Ripens from May 25th to June 10th.

Slappy, a large yellow freestone ripening about the first of July; one of our favorites.

Red Nectarine, a cross between a peach and a plum.

Per

Each Thousand

12 to 18 inches__-_._._._- $\$ 0.10 \$ 80.00$

18 to 24 inches_._._.

24 to 36 inches____._._. $.15 \quad 120.00$

Mayflower, Greensboro, Carman, Belle of Georgia, Elberta.

\section{APPLE TREES}

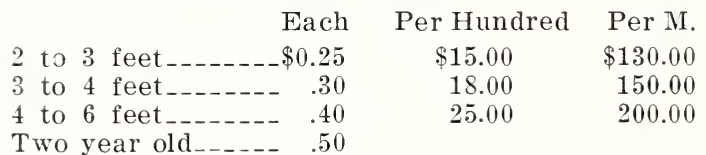

\section{APPLES-ONE AND TWO YEAR PRICE}

We have the very best selection of apples, all of which have been tested and found to be very prolific. Many prizes have been won by us on exhibition of our apples at State Fairs, etc.

\section{COMMERCIAL APPLES FOR SHIPPING:}

DELICIOUS-Large, oblong, obtuse, conical, dark color, brilliant red blended golden yellow at the tip. Quality exquisitely fine. Keeping and carrying qualities unsurpassed by even Ben Davis. Best seller on the market. Ripens in the Fall. Buyer can safely set a good many of these for the market. Bears in four years.

STAYMAN'S WINESAP_Large apple, beautiful red, best quality, good keeper, vigorous grower. Very popular; great many now being set out for marketing.

YATES-Tree very upright, gieat bearer and keeps excellently. Flesh wh:te, sometimes stained next to the skin; tender, juicy, sub-acid, will keep until May.

WINESAP-Not only a good apple for the table but is fine cider apple. Tree bears early, is very hardy and is a most profitable orchard variety wherever grown. Flesh yellow, firm, crisp, with a rich, high flavor. Ripens November, will keep until May.

Home orchard apples; sometimes used for commercial: 
TAYLOR NO. 1-This is an exceedingly fine variety. J. P. Taylor, Greer, S. C., originator. Fruit large, oblong to conical in shape. Flesh rich creamy yellow; color beautiful red with white dots. Very highly flavored; aromatic, crisp, firm. Keeps well. Ripens from October 1st to December 1st. Has won lots of prizes. Heavy bearer.

ROUGH AND READY-J. P. Taylor, originator; the best prolific late winter apple; will keep until May.

ARKANSAS BLACK-Large improved winesap; flesh firm, crisp, with high, rich flavor. Elegant flavor. Not a commercial apple.

TERRY WINTER - A very prolific bearer; medium size, red with white stripe. Used in commercial orchards to medium extent.

WINTER BANANA-Beautiful apple. Very large, hardy and prolific bearer. Flesh yellowish white, excellent sub-acid flavor, resembles a banana. Keeps well.

GRIMES GOLDEN-An early Fall apple; not a heavy bearer in South Carolina, but bears well in North Carolina. A good, commercial bearer; yellow, juicy with delicious flavor.

\section{SUMMER APPLES}

WILSON'S RED JUNE-Early bearer, very prolific, red with some white, larger than Carolina Red June and a better apple. Fine market apple.

RED ASTRACHAN - Very valuable variety, especially for the market and for all kinds of culinary uses. Ripens last of June and the first of July.

EARLY HARVEST-Yellow apple, heavy bearer, good cooking apple, fine for the market.

YELLOW TRANSPARENT-Yellow apple; will bear at two years old; good market apple. Ripens last of June.

\section{APRICOTS}

2 to 3 feet_-_._.

3 to 4 feet_... .50

ALEXANDER - Very prolific, ripens in June. Fruits well in this state.

\section{PLUMS}

3 to 4 feet_...

4 to 6 feet

RED JUNE-For the market value this is perhaps unequalled among Japanese plums. Ripens in early part of June. Large size, free from rot, color is most fiery red.

SHIRO-Ripens the same time. Yellow in color. Sweet. Good market plum. Very prolific. Free from rot to some extent.

SHROPSHIRE DAMSON-Very prolific, hardy, fine for culinary purposes.

\section{CHERRIES}

2 to 3 feet._.

3 to 4 feet_...

4 to 6 feet_....... 
GOV. WOOD-Tree vigorous and very productive. Deserves a place in every first-class collection. Large fruit; tender flesh; juicy, sweet and delicious. Ripens in May.

EARLY RICHMOND-One of the hardiest of all cherries; bears early and abundantly, a most valuable market fruit. Ripens in May and June.

BLACK HEART-Very prolific bearer, sweet; ripens in May.

MAY DUKE-This is a very valuable early cherry. It is the richest of all sub-acid cherries. Ripens the first to the last of May.

BALDWIN-Very best June cherry on the market today; will fruit heavy every year. Always produces when others fail to bear.

\section{EARLY PURPLE PEARS}

2 to 3 feet_......... 35

3 to 4 feet

4 to 6 feet._. 80

Two year old_......... 1.00

We handle but two varieties of pears, which we consider the best:

KIEFFER-Flesh firm and juicy, rich with pleasant vinous flavor; of good quality. Ripens in Fall. A good, preserving pear.

GARBER-Very prolific; juicy; ripens in early Fall. A good market pear.

\section{GRAPES}

1 year old $\$ .30$

2 year old

CONCORD-The grape for the millions; stands without a peer for general cultivation; heavily vine, vigorous and productive. Ripens early and is black.

MOORE DIAMOND-A white grape; ripens two or three weeks earlier than the Concord.

WYOMING RED-A very prolific grape; a good market and wine grape.

MOORE EARLY-Among the earliest of grape, black.

NIAGARA-White, best market and most prolific grape grown.

SCUPPERNONG-White, very prolific.

DELAWARE--What this grape lacks in size is made up in quality and productiveness. The vine is a vigorous grower, hardy and productive. Ripens early in September.

CATAWBA--Well known as the great wine grape as well as early winter table grape. Bunch and berry medium. A profitable market sort on account of its long keeping qualities.

WORDEN-This has deservedly won its reputation as being one of our finest grapes. Vine very healthy and never fails to bear good crops.

CAMPBELL'S EARLY (LUTIE)-Finest quality black table grape, unusually large berries make up very firm, compact bunches that simply look "quality" and the taste proves it. There is nothing finer in table grapes. 
BRIGHTON-Earlier than Delaware, double its size; equal in quality, vigorous grower and hardy even in Canada and northern New York.

LUCILE-Very large red grape, similar to the Concord in size; bears heavy and a fine grape for market.

PACKLINGTON-Large clusters and berries; yellowish green when ripe; juicy and tender, with very little pulp. Vine is hardy and productive. Ripens later than the Concord and keeps well.

SALEM-A good reliable variety, well colored, sprightly flavored.

\section{FIGS}

1 year old $\$ .50$

2 year old .75

BROWN TURKEY-Very prolific; small, has fine flavor, can be eaten without peeling and without irritation to mouth.

\section{BERRIES}

RED RAZZBERRIES $\$ 1.20 \mathrm{doz}$. BLACK RAZZBERRIES $1.20 \mathrm{doz}$.

\section{PECANS}

2 to 3 feet

3 to 4 feet._._.

4 to 6 feet

We have been growing pecans for a number of years and have found the following varieties to be the most prolific in this state.

STUART-Very large, paper shell, not very long.

SCHLEY-Paper shell.

Information on any nursery product not herein listed will be gladly furnished free of charge.

There are no packing charges on fruit trees.

We are well supplied with shrubbery, and can do landscaping. Write us about it.

\section{ROSES}

HYBRID TEA ROSES:

ANTOINE RIVIERE-Rosy flesh on yellow ground. Forces.

BESSIE BROWN-Creamy-white flowers; sweetly scented.

ETOILE De FRANCE-Color a lovely shade of clear, red crimson velvet, very fragrant.

HELEN GOULD-A grand rose of the very highest. merit for the garden; bright watermelon red; very free grower and bloomer.

KAISERIN AUGUSTA VICTORIA-Pure white with shading of primrose yellow.

La FRANCE-Queen of all the roses. Beautiful bright silvery pink with pale lilac shading.

RED RADIANCE-All who know that grand rose radiance will welcome this red form of that great favorite. Radiance is a rose that grows well 
everywhere. A fine grower and free bloomer. No prettier pink rose grown. Red Radiance is its exact counterpart except that the color is rich deep red.

RHEA REID-Flower large and double; rich dark velvet red; a good red garden rose.

ALEXANDER HILL GRA Y - Color is solid deep yellow throughout.

ETOILE De LYON-Bright sulphur yellow; fine form large size; fine yellow.

PAPA GON'TIER-Rosy crimson, fine long bud; most attractive; forces.

GENERAL ROBERT E. LEE-Orange yellow; shade white; free.

MAMAN COCHET-The famous pink cochet. Light pink shade with salmon yellow outer petals splashed with bright rose; extremely large and full.

WHITE MAMAN COCHET-A sport from maman cochet, with creamy white flowers faintly tinged with blush.

WHITE AMERICAN BEAUTY - This grand rose has become renowned as the very highest type and is the best snow-white rose ever introduced. It is an extraordinary strong grower and has the vigor and hardness of an oak. Its magnificent flowers are nothing less than glorious, immense in size and produced with great freedom. The color is marvelous white without tinge of yellow or any other shade. A true paper white, the standard by which all white roses are judged.

GENERAL JACQUEMINOT-Crimson scarlet; large, full, very fragrant. Excellent.

We will be pleased to furnish any additional information regarding roses which you may desire.

PINK RADIANCE-Brilliant rose-pink buds open to well formed shining flowers with lighter tints on the reverse side of the petals; globular in shape and very fragrant. The plants make splendid growth, has wonderful blooming qualities.

AMERICAN BEAUTY (PINK) - This magnificent rose produces immense rose-pink blooms on every shoot; it never clusters and can be cut with very long stems. Desirable for winter forcing.

SUNBURST-The color is orange-copper or golden orange and golden yellow; edge of petals lighter; all intense shades; extremely brilliant in effect; some call the color codmium-yellow. It is the yellowest of all roses in the everblooming class.

LUXEMBERG-Yellow rose.

\section{CLIMBING ROSES}

AMERICAN BEAUTY-Same color, size and fragrance as American Beauty, with the addition of the climbing habit; good foliage and better blooming qualities. One plant of this new rose will produce twenty times as many flowers in June as the older American Beauty.

DOROTHY PERKINS-A splendid, new climbing rose. In foliage and habit of growth it is remarkably like crimson rambler; the flowers are double, of good size and borne in clusters. the petals are very 
prettily rolled back and crinkled; buds remarkably handsome; color a clear shell pink and holds a long time without fading.

DR. W. VAN FLEET-Flowers when open run four inches and over in diameter. The center is built high, petals beautifully undulated and cupperl. The color is a remarkable delicate shade of fleshpink on the outer surface, deepening to rosy in the center.

SILVER MOON-White rose.

MARCHAL NIEL-This is the old standby yellow rose in the South, where it is hardy; indeed it will bloom in any garden but is not hardy in the North. Immense deep golden yellow flowers with the deepest, richest tea fragrance of all roses.

CRIMSON RAMBLER-Bright crimson flowers produced in large clusters of pyramidal form, grand variety for pillars and arches and to train over porches. Also makes a fine attractive hedge.

LADY HILLINGDON-A climbing sport of the popular variety of the same name; a fine climber for walls or under glass, makes exquisite buds of deep apricot yellow, shading to orange. Deliciously fragrant.

\section{PRICES ON ABOVE ROSES}

Each

All except American Beauty_-_-_-_\$ .50-1 year old All except American Beauty_-_-_- $.60-2$ year old American Beauty_........... .75-1 year old American Beauty_............. 1.00-2 year old

If there is any further information desired regarding any of the above, we will be pleased to furnish same free of charge.

Visitors are welcome at our nursery at any time except Sunday. The nursery is located on the National Highway about two miles from Greer, S. C. We will be pleased to furnish additional pamphlet upon request.

Orders received will be filled promptly. Please send money order or certified check with order or will fill order C. O. D.

\section{CONIFEROUS EVERGREENS}

Retinospora Ericoides (Tom Thumb), dwarf.

10 to 15 in........ $\$ 1.50$

15 to 24 in.-_... 3.00

Retinospora Obtusa Nana, dwarf.

12 to 18 in.-_ $\$ 3.00$

Retinospora Pisifera.

12 to 15 in.-_- $\$ 1.50$

Retinospora Pisifera Argentia Aurea, golden Sawara cypress.

8 to $12 \mathrm{in.}$

12 to 15 in..-_... 2.50

\section{Retinospora Pisifera Aurea.}

2 to 3 feet._._.

3 to 4 feet__._. 
Retinospora Plumosa, plume cypress.

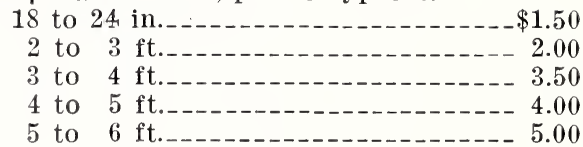

Retinospora Plumosa Aurea, golden plume cypress.

18 to 24 in............... $\$ 2.00$

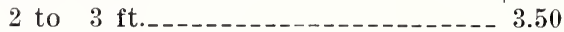

3 to $4 \mathrm{ft} . \ldots$

Retinospora Squarrosa Seiboldi (Purple).

12 to 15 in...-...- $\$ 1.50$

15 to 24 in.-_...

Retinospora Squarrosa Veitchi, silver cypress.

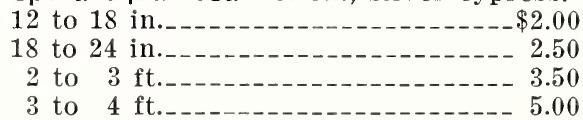

Retinospora Viridissima.

18 to 24 in...- $\$ 1.50$

2 to $3 \mathrm{ft.}$

3 to $4 \mathrm{ft.}$

4 to $5 \mathrm{ft.} .-\ldots$

Cryptomeria Japonica, Japanese cedar.

2 to 3 ft._._._. $\$ 2.00$

3 to 4 ft............ 3.00

4 to $5 \mathrm{ft.}$

Cephalotaxus Harrintonia Fastigata, upright yew.

12 to 18 in............ $\$ 2.50$

18 to 24 in.........

Cedrus Atlantica, Atlas cedar.

18 to 24 in.......... $\$ 3.00$

Cedrus Deodora, true cedar, silvery foliage.

12 to 18 in........... $\$ 2.00$

18 to 24 in..........

2 to $3 \mathrm{ft}$.

3 to 4 ft._-_._- 5.00

4 to $5 \mathrm{ft} . \ldots$

Lawson Cypress, (Blue green).

2 to 3 ft.......... $\$ 3.00$

3 to 4 ft......

Cupressus Rebunii (Blue).

18 to 24 in... $\$ 2.50$

2 to $3 \mathrm{ft.} . \ldots$

Juniperus Ashfordi, upright juniper.

2 to 3 ft.......... $\$ 2.50$

3 to 4 ft._._._._._. 5.00

Juniperus Chinensis Densa Glauca, compact dwarf

blue Chinese juniper.

12 to 18 in...... $\$ 2.00$

18 to 24 in........... 3.00

Juniperus Communis, common English juniper.
2 to $3 \mathrm{ft}$
$\$ 2.50$
3 to $4 \mathrm{ft}$
4.00
4 to $5 \mathrm{ft}$
5.00

Juniperus Douglassi Aurea, golden spreading juniper.

12 to 18 in.._...

18 to 24 in.............. 2.50

2 to $3 \mathrm{ft}$.

Juniperus Hibernica, Irish juniper.

2 to $3 \mathrm{ft.}$._-_-_._- $\$ 2.50$

3 to 4 ft._._-_._- 4.00

4 to 5 ft........ 
Juniperus Japonica, Japanese juniper.

18 to 24 in.

24 to 30 in.

Juniperus Nana, flat spreading juniper.

18 to 24 in.

2 to $3 \mathrm{ft} .-\ldots-\ldots-\ldots-00$

4 to $5 \mathrm{ft.}$

Juniperus Oblonga Pendula, drooping juniper.

18 to 24 in....... $\$ 1.50$

2 to $3 \mathrm{ft.}$

3 to $4 \mathrm{ft}$.

4 to 5 ft.....- 5.00

Juniperus Pfitzeriana, Pfitzea's spreading juniper, (the most popular).

18 to 24 in.

2 to $3 \mathrm{ft}$.

Juniperus Sabina, Savin juniper.

12 to 18 in...... $\$ 1.50$

18 to 24 in.

Juniperus Shuki, Chinese variegated leaf juniper.

12 to 18 in...... $\$ 2.00$

18 to 24 in......... 3.00

2 to $3 \mathrm{ft} . \ldots \ldots$

Juniperus Triparta.

18 to 24 in.

2 to $3 \mathrm{ft}$.

Juniperus Waukegan, gray carpet juniper.

18 to 24 in.... $\$ 2.00$

Juniperus Sabina Horzontalis.

18 to 24 in........ $\$ 1.50$

2 to $3 \mathrm{ft} . \ldots \ldots-\ldots$

Picea Excelsa, Norway spruce.

10 to 12 in........... $\$ 1.50$

12 to $18 \mathrm{in}$

Picea Pungens, Colorado blue spruce.

10 to $12 \mathrm{in.}$

12 to $18 \mathrm{in}$

Pinus Montana Mugo.

12 to 15 in.

Thuya Orientalis, Chinese arborvitae.

2 to $3 \mathrm{ft}$.

3 to 4 it.

4 to $5 \mathrm{ft}$.

Thuya Orientals Aurea Nana, Berckman's golden arborvitae.

12 to 18 in. 18 to 24 in. $\$ 2.00$

18 to 24 in.

2 to $3 \mathrm{ft}$.

Phuya Orientalis Aurea Pyramidalis, golden pyramidal arborvitae.

18 to 24 in

2 to $3 \mathrm{ft}$

4.00

Thuya Orientalis Dailey Nana, very compact, green arborvitae.

18 to 24 in.

2 to $3 \mathrm{ft}$.

Thuya Globosa, Globe arborvitae.

10 to 12 in.

12 to 15 in.

Thuya Occidentalis Columbia, white tipped arborvitae.

18 to 24 in.

2 to 3 ft......- 3.00 
Thuya Occidentalis Ellwangeriana, Tom Thumb arborvitae.

12 to 18 in....... $\$ 1.50$

18 to 24 in......... 2.50

2 to $3 \mathrm{ft} . \ldots \ldots \ldots$

Thuya Occidentalis George Peabody, golden aborvitae.

18 to 24 in.

2 to $3 \mathrm{ft}$.

Thuya Hoveyi, Hovey's globe arborvitae.

18 to 24 in............... $\$ 2.50$

White Pine.

2 to 3 ft.
3 to 4 ft.
4 to 5 ft.

Arizonia Cypressus.

18 to 24 in...... $\$ 1.50$

2 to $3 \mathrm{ft} . \ldots \ldots$

3 to $4 \mathrm{ft}$.

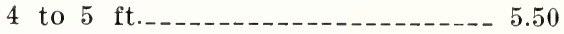

Italian Cypressus.

18 to 24 in......... $\$ 1.50$

2 to $3 \mathrm{ft} . \ldots \ldots \ldots \ldots$

3 to 4 ft...... 3.00

4 to $6 \mathrm{ft.}$

\section{Biota Rosdale.}

12 to $18 \mathrm{in.}$

18 to 24 in.

Thuya Pimula, dwarf arborvitae.

12 to 18 in.
18 to 24 in. $\$ 2.00$
24 to 30 in.

Thuya Occidentalis Plicata Pyramidalis, giant pyramidal arborvitae.

18 to 24 in...... $\$ 2.00$

2 to 3 ft.

Thuya Occidentalis Reidi, Reid's arborvitae.

18 to 24 in...... $\$ 2.50$

24 to 30 in........ 3.50

Thuya Occidentalis Warreana, Siberian arborvitae.

18 to 24 in.

24 to 30 in........ 3.50

Tsuga Canadensis, hemlock spruce.

18 to 24 in.

2 to $3 \mathrm{ft}$.

3 to $4 \mathrm{ft}$.

\section{BROAD LEAF EVERGREENS}

Abelia Grandiflora, best broad leaf evergreen for base planting, blooms all summer.

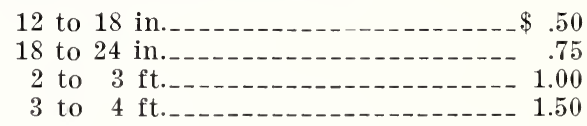

Aucuba Japonica, large evergreen, leaves spotted yellow.

12 to 18 in. $\$ 2.50$

Baxus Sempervirens, boxwood.

8 to 12 in..... $\$ .75$

12 to 15 in.-_-_- 1.25

15 to 20 in.._._.

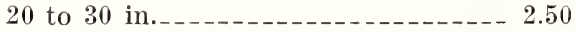


Crataegus Pyrancantha Lelandi, evergreen thorn,

(yellow or red berries).

18 to 24 in.......... $\$ 1.50$

2 to $3 \mathrm{ft}$

Eleagnus, extra broad leaf.

12 to 18 in............ $\$ 1.50$

Eleagnus Reflexa, bronze eleagnus.

18 to 24 in...... $\$ 1.50$

Eleagnus Variegata, (golden).

18 to 24 in...... $\$ 2.50$

Hypericum Moserainum, yellow bloom.

12 to 15 in........... $\$ 0$

Ilex Crenata, Japanese holly.

18 to 24 in.

2 to $3 \mathrm{ft} . \ldots$

Laurccerasus Caroliniana, cherry laurel, fine evergreen tree.

18 to 24 in........

2 to $3 \mathrm{ft}$.

Laurocerasus Officanal, English laurel.

18 to 24 in............... $\$ 2.50$

2 to $3 \mathrm{ft} . \ldots \ldots .50$

Budareia, (butterly bush).

2 to 3 ft._._.

3 to $4 \mathrm{ft}$.

Hedera Helix, evergreen; good ground cover in shady location, an ideal wall cover.

2 to 3 ft.........

Jasminum Nudiflorum, yellow, biooms early in the spring.

2 to 3 ft.

Ligustrum Lucidum, a very attractive evergreen with large glossy leaves.

18 to 24 in.

2 to 3 ft........... 2.00

Ligustrum Japonica, waxed leaf privet (large).

2 to $3 \mathrm{ft} . \ldots$

3 to $4 \mathrm{ft}$.

Lonicera Fragrantissima, fragrant white flower.

2 to 3 ft................ $\$$

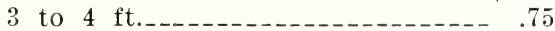

Photinia Seralata.

12 to 18 in.

Photinia Glabra, bright colored leaf.

12 to $18 \mathrm{in}$

Mahonia Aquifolium, Oregon holly grape, yellow flowers, blue-black fruit.

18 to 24 in.......... $\$ 1.50$

24 to 30 in.

Mahonia Japonica, Japanese mahonia, a broad leaved evergreen with leaves similar to holly, yellow flowers in June.

12 to $18 \mathrm{in.}$

Azalea Amonea.

10 to 12 in............ $\$ 2.50$

Azalea Henodigiri.

6 to 8 in.

10 to 12 in. 2.50 
Nandina Domistica, (red berries).

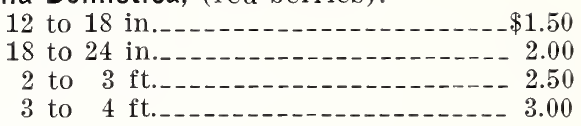

Lonicera Nitida, evergreen bush honeysuckle.

12 to 18 in. $\$ 1.00$

18 to 24 in.-_._.

2 to $3 \mathrm{ft} . \ldots-\ldots$

Magnolia Grandiflora, Southern magnolia.

2 to 3 ft............. $\$ 1.50$

3 to 4 ft._._._._._. 3.00

\section{HARDY DECIDUOUS FLOWERING SHRUBS}

Spirea Thunbergi, small feathery light green leaves (white).

18 to 24 in............ $\$$

2 to $3 \mathrm{ft}$........

Spirea $V$ an Houttei, drooping branches, flowers in bunches, (white).

2 to $3 \mathrm{ft} . \ldots$

3 to 4 ft._._-_._._.

Spirea Anthony Waterer, dwarf everblooming, (red).

18 to 24 in..-.... $\$ .50$

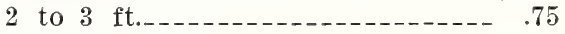

Spirea Callosa Alba, white, everblooming.

12 to 18 in......... $\$ .50$

18 to 24 in.-...-...-.

Berberis Thunbergi (red berries).

18 to 24 in.-...... $\$ 0$

New Japanese Red Leaf Barberry.

18 to 24 in.-_._- $\$ 1.00$

Dentzia Pride of Rochester (double pink).

3 to 4 ft. Rochester (double pink) $\$ .50$

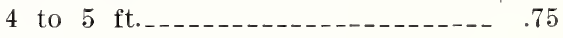

Forsythia Fortunei, arching branches.

2 to 3 ft._._._. $\$ .50$

Forsythia Viridissima, upright golden bell.

2 to 3 ft._._._.

Hydrangea Paniculata Grandiflora.

18 to 24 in.-... $\$ 0$

2 to $3 \mathrm{ft.}$.

Hydrangea Hills of Snow.

18 to 24 in........ $\$ 0$

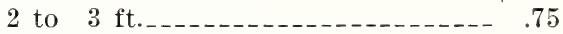

Jasminum Nudiflorum, naked flowering jasmine.

2 to 3 ft......... $\$$

Lagerstroemia Indica, crape myrtle, pink.

2 to 3 ft........... $\$ .75$

Lagerstroemia Indica, crape myrtle, red.

2 to 3 ft........ $\$ .75$

Lagerstroemia Indica, crape myrtle, purple.

2 to 3 ft._-_._._. $\$ .75$

Lagerstroemia Indica, crape myrtle, white.

2 to 3 ft........... $\$ 1.00$

Ligustrum Ovalifolium, variegated California privet.

12 to 18 in........ $\$ 1.00$

18 to 24 in.-........ 
Philadelphus Verginal, double white.

2 to 3 ft....... $\$ .50$

Weigela Rosea, pink.

2 to $3 \mathrm{ft}$.

Veburnum Opalis Steralis, common snowball.

2 to 3 ft.......... $\$ .50$

\section{DECIDUOUS SHRUBS}

Weigela Henderosia, flowering pomegranate.

\section{DECIDUOUS TREES}

Acer Platanoides, Norway maple.
3 to $4 \mathrm{ft}$
$\$ 1.25$
4 to 5 ft.
1.50
5 to $6 \mathrm{ft}$
$-2.50$

Acer Dasycarpum, silver maple.

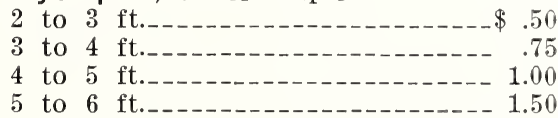

Amygdalis Persica Alba, white flowering peach.

2 to $3 \mathrm{ft}$.

3 to 4 ft......

Amygdalis Persica Rubra, red flowering peach.

2 to 3 ft.

3 to 4 ft.......... 1.00

Cercis Canadensis, red bud.

2 to $3 \mathrm{ft} . \ldots$.

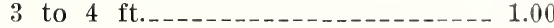

Cornus Florida Alba, white flowering dogwood.

3 to 4 ft........ $\$ .75$

4 to 5 ft.......... 1.00

Cornus Florida Rubra, red flowering dogwood.

2 to 3 ft..........

3 to $4 \mathrm{ft}$.

4 to $5 \mathrm{ft} . \ldots$

Lombardy Poplar.

6 to $8 \mathrm{ft} . \ldots$

8 to $10 \mathrm{ft}$.

10 to $12 \mathrm{ft}$.

Chinese Lombardy Poplar.

3 to 4 ft.................. $\$ 50$

4 to $5 \mathrm{ft}$.

5 to $6 \mathrm{ft}$.

\section{CLIMBING VINES}

Lonicera Heckrotti, everblooming honeysuckle.

2 to 3 ft................

3 to $4 \mathrm{ft}$

Wisteria Sinensis (purple).

2 to 3 ft..... $\$ 1.00$

Wisteria Sinensis Alba (white).

2 to 3 ft.

Amor River Privet Hedge.

18 to $24 \mathrm{in}$

2 to $3 \mathrm{ft}$

3 to $4 \mathrm{ft}$ 6.00 
Contract Growing and General

Horticulture Work 